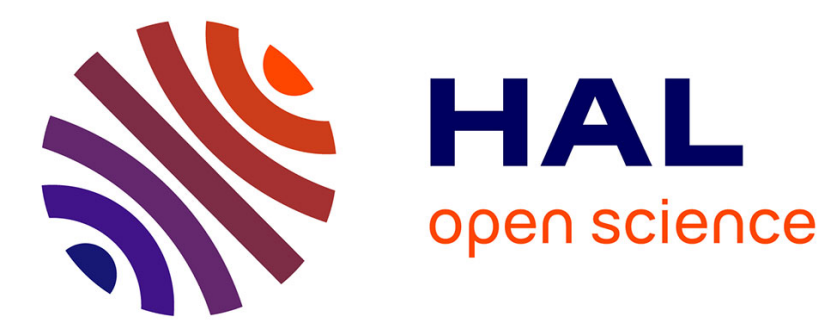

\title{
SOLID STATE LASERS TUNABLE IN THE VISIBLE SPECTRUM AND NON-LINEAR MATERIALS IN GLASSES
}

\author{
R. Reisfeld
}

\section{> To cite this version:}

R. Reisfeld. SOLID STATE LASERS TUNABLE IN THE VISIBLE SPECTRUM AND NONLINEAR MATERIALS IN GLASSES. Journal de Physique IV Proceedings, 1991, 01 (C7), pp.C7415-C7-418. 10.1051/jp4:19917106 . jpa-00250754

\section{HAL Id: jpa-00250754 https://hal.science/jpa-00250754}

Submitted on 1 Jan 1991

HAL is a multi-disciplinary open access archive for the deposit and dissemination of scientific research documents, whether they are published or not. The documents may come from teaching and research institutions in France or abroad, or from public or private research centers.
L'archive ouverte pluridisciplinaire HAL, est destinée au dépôt et à la diffusion de documents scientifiques de niveau recherche, publiés ou non, émanant des établissements d'enseignement et de recherche français ou étrangers, des laboratoires publics ou privés. 


\title{
SOLID STATE LASERS TUNABLE IN THE VISIBLE SPECTRUM AND NON-LINEAR MATERIALS IN GLASSES
}

\author{
R. REISFELD ${ }^{(1)}$
}

The Hebrew University of Jerusalem, IL-91904 Jenusalem, Israel

\begin{abstract}
A new family of solid state photostable tunable lasers in the visible is prepared by incorporation of a number of perylimide dyes into inorganic glasses or into composite materials prepared from inorganic glass with organic polymers. The lasers may be prepared in a bulk form or in thin films on a glass support, enabling single mode operation. The same techniques are also used for preparation of nonlinear materials whereby a large number of organic molecules or semiconductor particles are introduced into the glasses.
\end{abstract}

Recently, a considerable effort has been extended toward the search for tunable lasers made of solid inorganic materials operating in the visible part of the spectrum [1-7]. Toward this end, the sol-gel process for glass preparation is especially suitable. It enables single or multiple component glasses to be prepared at temperatures low enough in order not to destroy the organic molecules [8]. The glass preparation allows adding of an organic molecule to the solution to be homogeneously incorporated in the final glass provided the dye dissolves in the solvent from which the glass is prepared [8-10]. The resulting photostability of the dye is enhanced in the inorganic host matrix and surpasses that of organic media such as polymethylmethacrylate. However, despite this increased photostability, lasers prepared by the sol-gel method from conventional laser dyes can survive only a few pulses of exciting laser sources before degradation $[2,3,5-7]$.

The perylimide dyes used for laser preparation were developed by Seybold et al. [11] with a structure (derived from perylene) now published [12]. They are characterized by their extreme photostability and negligible singlet- triplet transfer which is responsible for nonradiative relaxations. The absence of a long-lived triplet state prevents photochemistry to take place and allows the existence of stable dyes with high quantum efficiency of fluorescence. Optical characteristics of several perylimide dyes [13] are presented in Table 1.

The perylene derivatives have limited solubility in conventional solvents from which the sol-gel glasses are prepared because of the planar structure of the molecules which facilitates the formation of crystals with high lattice energies. Fortunately perylene dyes can be introduced into composite glasses which are

(1) Enrique Berman Professor of Solar Energy 
Table 1: - Optical characteristics of perylimide dyes

\begin{tabular}{lcccc}
\hline Dye & $\begin{array}{c}\text { abs } \\
\max \mathrm{nm}\end{array}$ & $\begin{array}{c}\text { em } \\
\max \mathbf{n} \text { m }\end{array}$ & $\begin{array}{c}\text { extinction } \\
\text { coefficient }\end{array}$ & $\begin{array}{c}\text { quantum } \\
\text { efficiency }\end{array}$ \\
yellow & 474 & 508 & 48000 & $\%$ \\
orange & 525 & 540 & 85000 & 91 \\
red & 578 & 613 & 44000 & 100 \\
blue & 610 & 685 & 63000 & 96 \\
\hline
\end{tabular}

composed of mostly inorganic matrix with an addition of organic polymer [9]. We were able to introduce a variety of dyes into the composite glasses either in bulk glasses [14-17] or into thin films [18].

Already in 1971, Weber and Uhlrich [19] reported a successful operation of a solid thin film dye laser with waveguiding properties which is obtained by covering a polyurethane thin film of $0.8 \mu \mathrm{m}$ on a glass tube. This waveguiding thin film ring laser when pumped by a nitrogen laser was operating in $\mathrm{TE}_{\Theta}$ and $\mathrm{TM}_{\Theta}$ single modes. However, because of the unstability of the laser medium towards exciting laser radiation, there is a need to improve the photostability of the waveguiding laser system. This is performed by coating support glasses either as flat plates or tubes by composite glass films or specially prepared sol-gel films incorporating perylimide laser dyes. A typical procedure includes the following starting materials: Tetraethoxysilane (TEOS) and Tetramethoxysilane (TMOS) with addition of Tetraethoxytitanium $\mathrm{Ti}(\mathrm{OEt})_{4}$, which, by hydrolysis and polycondensation can vary the refractive index of the glasses between 1.45-1.7. In some cases, the addition of organic polymer is needed in order to enable the homogenous solution of perylimide dyes. Typical polymers are

PMMA polymethylmethacrylate<smiles>CC(C)C(=O)I</smiles>

GLYMO 3-(glycidoxypropyl) trimethoxysilane

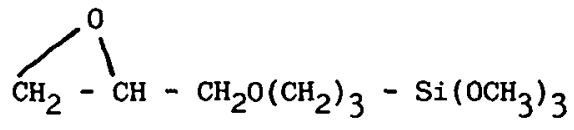

MEMO 3-methacryloxypropyltrimethoxysilane<smiles>CCCCC(CC)OC(=O)C(C)=O</smiles>

One typical example is: $48 \mathrm{~m} 1$ MEMO, $5.5 \mathrm{ml}$ water and $3.45 \mathrm{ml}$ methacrylic acid were stirred for $16 \mathrm{~h}$, then $20 \mathrm{ml} \mathrm{Ti}(\mathrm{OEt})_{4}$ and $20 \mathrm{ml}$ TEOS were added and continued stirring for $3 \mathrm{~h}$. Fluorescent dye BASF 241 was dissolved in concentration $10^{-4} \mathrm{M}$ in the starting solution. Thus, the molar ratio of TEOS:Ti(OEt) 4 :MEMO:water: methacrylic acid $=1: 1.1: 2.3: 3.4: 0.46[18]$. 
Film lasers may have some advantage over bulk lasers in the future because of their good thermal dissipation and waveguide properties. If the refractive index of the film is higher than that of the glass support the laser radiation is trapped and guided by a total internal reflection in the thin film.

The spectral range of the lasers obtained so far is between $500 \mathrm{~nm}-700 \mathrm{~nm}$. The slope efficiencies around $15 \%$ can be obtained.

By using the sol-gel techniques, we have also prepared glass bulks and films doped by CaS quantum dots [20], and organic molecules having nonlinear properties [21]. Third harmonic generation signals (THG) from CdS doped thin glass and/or ORMOCER films were easily observed. The strongest THG signals were about 1500-2000 times stronger than those generated by the glass substrate alone. This can be compared with the THG signals from CaS particles in a swollen polymer film deposited on quartz, which is 1.5 times higher than the corresponding signals from quartz alone when excited at $1.06 \mu \mathrm{m}$. Table 2 compares some typical values of the nonlinear third order susceptibility in various materials.

Table 2: Nonlinear optical materials; typical values of third order nonlinear susceptibility [21].

\begin{tabular}{|c|c|c|c|}
\hline Material & Matrix & {$[$ esu/cm } & Remarks \\
\hline CdS & glass film & $10^{-12}$ & THG, 1-10 w.t\% \\
CdS & bulk & $10^{-4}$ & \\
CuCl & sol-gel glas & $10^{-8}$ & microcrystallites \\
GaAs & MQW & $10^{-3}$ & \\
InSb & bulk & $6^{*} 10^{-3}$ & \\
CaSe & silica & $1.3^{*} 10^{-8}$ & sputtered film \\
PbI & pure & $10^{-4}$ & evaporated on quartz \\
semiconductors & glass & $10^{-11^{-1}}-7$ & commercial filters \\
Gold & glass & $1.5^{*} 10^{-8}$ & nanoparticles \\
Silver & glass & $4^{*} 10^{-10}$ & nanoparticles \\
polyacetylene & pure & $4^{*} 10^{-10}$ & Oriented film \\
polydiacetylene & pure & $2^{*} 10^{-9}$ & Film \\
PPV & pure & $(1-5)^{* 10^{-10}}$ & Film \\
Methyl orange & glass & $4^{*} 10^{-6}$ & composite glass \\
Acridine orange & glass & $2^{*} 10^{-4}$ & composite glass \\
phtalocyanine & pure & $10^{-8}$ & L-B films \\
Chrysoidine & PVA & $2^{*} 10^{-7}$ & Films \\
Fluorescein & boric acid & $\left(1-10^{*} 10^{-1}\right.$ & \\
\hline
\end{tabular}

PPV: Poly-(p-phenylene vinylene)

PVA: Polyvinyl alcohol.

MWQ: Multiple quantum wells.

THG: Third harmonics generation.

We have found a functional relation between the inflection point in the absorption spectrum and the particle size of CaS as obtained from X-Ray diffraction and from Transmission Electron Microscopy (TEM). The smaller the particles, the higher the energy of their absorption.

The quantum size effects, resulting from confinment of the electron and hole in a small volume were revealed by distinct electronic levels observed in excitation spectra of the particles embedded in the films [22]. 


\section{Acknowledgement}

The author is grateful to Dr. M. Eyal for discussion. The project was supported by US Air Force Office of Scientific Research, USAF, Contract FR9620-90-C-0073 DEF.

\section{References}

/1/ Reisfeld,R, Jorgensen,C.K, " Optical properties of colorants and luminescent species in sol-gel glasses, Structure and Bonding, 77 (1991), Editors R. Reisfeld and C.K. Jorgensen, Springer-Verlag.

/2/ Kobayashi, Y, Kurokawa,Y, Imay, Y, J, Non-Cryst. Solids 105 (1988) 198.

/3/ Dunn,B, Knobbe,E, Mckiernan,J, Pouxviel,J.C, Zink,J.I, Proc. MRS Symp. 121 (1988) 331

14/ Salin,F, Lesaux,G, Georges,P, Brun,A, Bagna11,C, Zarzycki, J, Opt. Lett. 14 (1989) 785.

/5/ Reisfeld,R, J. Phys. Colloq. 48(C7) (1987) 423.

/6/ Altshuler, G.B, Bakhanov,V.A, Dulneva,E.G, Erofeev,A.V, Mazurin, 0.V. Roskova, G.F.P, Teskhomskaya,T.S, Opt. Spectrosc. 62 (1988) 707.

/7/ McKiernaw, J.M. Yamonaka, S.A, Dunn, B and Zink, J.I, J. Phys. Chem., 94 (1990) 5652 .

/8/ Avnir,D, Levy,D, Reisfeld,R, J. Phys. Chem. 88 (1984) 5956.

/9/ Pope,E.J, Mackenzie,J.D, MRS Bull. 12 (1987) 29.

/10/ Reisfeld,R, Brusilovsky,D, Eyal,M, Miron,E, Burshtein,Z, Ivri,J, Chem,

Phys. Lett. 160 (1989) 43.

/11/ Reisfeld,R, Seybold,G, J. Luminescence 48 (1991) 808.

/12/ Reisfeld,R, Seybold,G, Chimia, 44 (1990) 295.

/13/ Seybold,G, Wagenblast,G. Dyes Pigments, 11 (1989) 303.

/14/ Reisfeld,R, Brusilovsky,D, Eyal,M, Miron,E, Burshtein,Z, IVRI,J, Proc. Binational French-Israeli Workshop of Solid State Lasers, SPIE Proc. 182 (1989) 230 .

/15/ Reisfeld, R. Chernyak, V, Spectroscopic behavior of Malachite Green in Sol-Gel Glasses, accepted for publication by Chem. Phys. Lett. (1991).

/16/ Eyal,M, Reisfeld,R, Chernyak, V, Kaczmarek, L. and Grabowska, A., Chem. Phys. Lett. 176 (1991) 531 .

/17/ Gvishi,R, Reisfeld,R, A new solid state laser for photodynamic therapy. To be published in Proc. of Laser M2P Conference, Grenoble, France, July, 1991.

/18/Chernyak, V, Reisfeld,R, Laser properties of thin film coatings with perylimide dyes on glasses, to be published.

/19/Weber,H.P. Uhlrich,R, Appl. Phys. Let., 19 (1971) 38.

120/ Minti,H, Eyal,M, Reisfeld,R, "Quantum dots of Cds in thin glass films prepared by the sol-gel technique", submitted to Chem. Phys. Lett. (1991).

/21/ Reisfeld,R, Semiconductor quantum dots in amorphous materials, to be published in the proceedings of NATO ASI on Optical Properties of Excited States in Solids (1991), Editor B. Di Bartolo, Plenum Publ. Co.

/22/Reisfeld,R, Minti,H, Eyal, M, Proc. Int'I Congress on Optical Sciences and Engineering, 10-11 March, 1991 Hague, SPIE 1513 (1991). 